\title{
Dilated Cardiomyopathy Concomitant with Acute Rheumatic Fever and Sporadic Hereditary Spherocytosis
}

\author{
Amelin, $\mathrm{F}^{1}$, Hariyanto $\mathrm{D}^{2}$, Izzah $\mathrm{AI}^{3}$ \\ ${ }^{1,2,3}$ Pediatric Department of Andalas University/ Dr.M.Djamil Hospital, Padang, Indonesia \\ E-mail : fitrisiaamelin@med.unand.ac.id
}

\begin{abstract}
Background: Dilated cardiomyopathy (DCM) is a heart muscle disorder defined by the presence of a dilated and poorly functioning left ventricle in the absence of abnormal loading conditions (hypertension, valve disease) or ischaemic heart disease sufficient to cause global systolic impairment. Case report: A 5 years old and 6 months old girl with unremarkable cardiac history hospitalized for congestive heart failure due to dilated cardiomyopathy concomitant with acute rheumatic fever and sporadic hereditary spherocytosis. Acute rheumatic fever diagnosed based on the presentation of carditis, fever, high erythrocyte sedimentation rate, C-Reactive Protein $(+)$, and antistreptolysin titer $\mathrm{O}(+)$. DCM was diagnosed after echocardiography. Sporadic hereditary spherocytosis was diagnosed based on anamnesis of pale and jaundice, splenomegaly on physical examination, hemolytic anemia, reticulocytosis, spherosit $(+)$. Both parents reveals normal hematologic finding and the osmotic resistance test showed increasing of osmotic fragility. Conclusion: Prognosis of this patient remains worse because of inadequate left ventricle-right ventricle (LV-RV) function and highly increasing The $\mathrm{N}$ terminal prohormone of brain natriuretic peptide (NT-proBNP) level.
\end{abstract}

Keywords : dilated cardiomyopathy-acute rheumatic fever- sporadic hereditary spherocytosis

\begin{abstract}
Abstrak
Latar belakang: Kardiomipati dilatasi (DCM) adalah kelainan otot jantung yang ditandai oleh adanya dilatasi dan penurunan fungsi ventrikel kiri tanpa adanya kondisi pembebanan abnormal (hipertensi, penyakit katup) atau penyakit jantung iskemik yang menyebabkan kerusakan sistolik global. Laporan kasus: Seorang anak perempuan berusia 5 tahun dan 6 bulan dengan tanpa adanya riwayat penyakit jantung dirawat dengan gagal jantung kongestif karena kardiomiopati dilatasi dan demam rematik akut serta sferositosis herediter sporadis. Demam rematik akut didiagnosis berdasarkan adanya karditis, demam, peningkatan sedimentasi eritrosit, $C$ Reactive Protein (+) dan anti-streptolysin titer $O(+)$. DCM didiagnosis dengan ekokardiografi. Sferositosis herediter sporadis didiagnosis berdasarkan anamnesis pucat dan ikterus, splenomegaly, anemia hemolitik, retikulositosis, sferosit (+). Kedua orang tua dengan hematologi normal dan uji resistensi osmotik menunjukkan peningkatan kerapuhan osmotic sel darah. Kesimpulan: Prognosis pasien ini buruk karena fungsi ventrikel yang buruk dan peningkatan prohormon N-terminal tingkat natriuretik peptida otak (NT-proBNP).
\end{abstract}

Katakunci : kardiomiopati dilatasi-demam rematik akut-sferositosis herediter sporadis

Email : heme@unbrah.ac.id 


\section{INTRODUCTION}

Dilated cardiomyopathy (DCM) is a heart muscle disorder defined by the presence of a dilated and poorly functioning left ventricle in the absence of abnormal loading conditions (hypertension, valve disease) or ischaemic heart disease sufficient to cause global systolic impairment ${ }^{1}$. The most common cause of DCM is idiopathic (60\%), familial cardiomyopathy, active myocarditis (caused by viral), and other cause included infectious other than viral infection (bacterial, fungal, protozoal, rickettsial), as well as an endocrine metabolic disorder, nutritional disorder, and cardiotoxic agent ${ }^{2}$.

DCM is a rare case in the pediatric population but the most common form of pediatric cardiomyopathy and the most common indication $(64 \%)$ for heart transplantation in children over the age of 5 years ${ }^{3,4}$. It also represents a common indication for transplant in infants $(31 \%)^{4}$. The incidence of DCM children is 0,57 cases per 100.000 per year overall, higher in boys than in girls, in black people than in white people, and in babies younger than one year than in children. Two-thirds of children are thought to have the idiopathic disease. A five years mortality rate after time of diagnosis approximately $35-70 \%$.

There are very few clinical signs until DCM is severe. In smaller children, any history of cough, decreased effort tolerance, poor feeding, failure to thrive, syncopal episodes, or chest pain should result in a thorough examination looking for cardiomegaly and clinical signs of cardiac failure ${ }^{6}$. The majority of patients demonstrated moderate or severe left ventricular dysfunction on initial echocardiogram, and $6 \%$ of patients died in the initial hospitalization ${ }^{7}$. Some mild DCM cases found from forensic autopsies of unexpected cardiac death in asymptomatic pediatric patients during anaestesia ${ }^{6}$. Despite advances in diagnosis and therapy, the natural progression of DCM reported in children has not improved dramatically. Nearly all cases of DCM in children progress to end-stage heart failure and the need for cardiac transplantation ${ }^{5}$.

The purpose of this case is to present a rare case of pediatric dilated cardiomyopathy, which first hospitalized concomitantly with acute rheumatic fever and sporadic hereditary spherocytosis. We report the clinical manifestation, diagnosis approach, and management of this case.

\section{CaSe Report}

A 5 years and six months old girl has first hospitalized in pediatric ward M. Djamil hospital with chief complaint shortness of breath two weeks before admission.

The child got a fever since one and a half months ago; the temperature was not high, intermittent, there was no shivering. Cough since one and a half months ago, without influenza, and productive, frothy and sometimes hemorrhagic sputum, amount half until a spoonful. Exercise intolerance since one month ago, at that time, the child said that she was difficulty breathing after she went upstairs, and then she could not walk upstairs and also could not play with her classmate in Kindergarten. The stomach became bigger since one month ago and followed by abdominal pain since two weeks ago. The urine color become dark since 1 month ago. Look pale since 1 month ago, and worsening before admission. Shortness of breath since two weeks ago, and in these two weeks, the child got breathlessness during rest and sleep on two pillows. History of sore throat and recurrent upper respiratory tract infection was unremarkable. No history of joint pain, uncontrolled movement, pink rings on the trunk, and inner surfaces of the limbs. No history of cyanotic since birth, and excessively sweat after feeding and exercise. There was no history of gum, nose, and digestive bleeding. There was no history of transfusion. There was no history of close 
contact with a tuberculosis patient. Bowel movement was normal. The child has been hospitalized in Kerinci District Hospital for two days, and has been checked the laboratory with the result hemoglobin 11,1 $\mathrm{gr} / \mathrm{dL}$, leucocyte $20.300 / \mathrm{mm} 3$, hematocrit $36 \%$, HbsAg was negative, alanine aminotransferase (ALT) $65 \mathrm{U} / \mathrm{L}$, and aspartate aminotransferase (AST) $26 \mathrm{U} / \mathrm{L}$.

The patient never suffered from a disease like this before. Her aunt (mother's sibling) suffered from heart disease concomitantly diagnosed antepartum and died after delivery in 2008 without a previous history of heart disease. There is no other family member who suffered from heart disease, hematologic disorder, and jaundice.

The patient was single child, spontaneous vaginal delivery assisted by a midwife, aterm with birth weight of 3000 gram and birth length $50 \mathrm{~cm}$, vigorous, she was discharged home in the second day of life without a medical problem. Primary immunization was completed according to the Public Health Programme. The history of growth and development was standard. Before hospitalized, she just started to play and learn in Kindergarten. Hygiene and sanitation quite good. She lived in a suburb area.

Her mother was 22 years old, graduated from junior high school, housewife. Her father was 23 years old, graduated from junior high school, work as a public relations staff. The patient and her family live in their relative's home, a permanent house with good hygiene and sanitation.

Patient look severely ill, sleep by sitting position lean on three pillows, blood pressure $90 / 60 \mathrm{mmHg}$, heart rate 156 times per minute, respiratory rate 54 times per minute, body temperature $38,5^{\circ} \mathrm{C}$, oxygen saturation $90 \%$, body weight $15 \mathrm{~kg}$ with edema, body height $101 \mathrm{~cm}$, weight for age was 78,9\%, height for age was $90,9 \%$, weight for height was $93,7 \%$, with impression short familial stature, there was anemic, jaundice, edema and no cyanotic. The skin was warm. There was no regional lymph enlargement. Head was round and symmetric, palpebra was edema, conjunctiva was anemic, sclera was icteric, pupil was isochors with diameter $2 \mathrm{~mm} / 2 \mathrm{~mm}$, light reflex was positive normal. Ears were normal. There was a nasal flare. Tonsil was T1-T1, not hyperemic, and pharynx was not hyperemic. Mucous in the mouth was wet, no oral thrush. Jugular venous pressure (JVP) $5+2 \mathrm{cmH}_{2} \mathrm{O}$. The chest was symmetric; there was an epigastric retraction, heart: apex was not inspected, the apex was palpable at one finger lateral of left midclavicular line, intercostal space $\mathrm{V}$, heart border: above: RIC II, dextra: sternalis dextra line, Sinistra: 1 finger lateral left midclavicular line, heart sound: regular rhythm, the murmur was not obviously heard, lung: vesicular, rales $+/+$, no wheezing. There was no abdominal distension, no venectation, no collateral vein, liver was palpable $3 / 4-3 / 4$, blunt margin, homogenous, and the spleen was palpable Schoeffner 2, shifting dullness (+). Genitalia: no abnormality, puberty state $\mathrm{A}_{1} \mathrm{M}_{1} \mathrm{P}_{1}$. Extremities was warm with good perfusion, physiological reflex were positive normal, pathological reflexes were negative, pretibial edema $(+/+)$.

Laboratory finding revealed haemoglobin 8 $\mathrm{gr} / \mathrm{dL}$, leukocyte $15.600 / \mathrm{mm}^{3}$, differential count 0/0/1/72/26/1. Impression: neutrophilia shifts to the right. Hematocrit $24 \%$. Thrombocyte 425.000/mm3. Reticulocyte $14,9 \%$. Erythrocyte $2,7 \times 10^{6} \mathrm{~mm} 3$, peripheral blood smear showed normochromic anisocytosis, polychromatic, Phragmentocytes (+), erythrocyte, lymphocyte atypic (+), thrombocyte was normal. Erythrocyte sediment rate $15 \mathrm{~mm}$ in the first hour. MCV: $88,88 \mathrm{fl}, \mathrm{MCH}: 29,62$ PQ, MCHC : 33,3\%. Mentzer index: 32,91 Interpretation: Normocytic normochromic moderate anemia ec. Suspect hemolytic. Advice: Coomb's test 
Urinalysis findings no proteinuria, reduction was negative, leukocyte 0-1/LPB, erythrocyte $\quad 0-1 / \mathrm{LPB}, \quad$ bilirubin $(-)$, urobilinogen (-). Routine feces revealed normal.

The diagnosis of this patient is congestive heart failure grade IV, left ventricle hypertrophy ec. Acute rheumatic fever. Differential diagnosis: cardiomyopathy and hemolytic anemia ec suspect spherocytosis.

Treatments were $\mathrm{O}_{2} 2$ liters/minute, liquid food 6 x $200 \mathrm{cc} / \mathrm{NGT}$, furosemide 1x $15 \mathrm{mg}$ IV, spironolacton $2 \times 12,5 \quad \mathrm{mg} \quad \mathrm{IV}$, paracetamol $125 \mathrm{mg}$ po $\left(\mathrm{T} \geq 38,5{ }^{0} \mathrm{C}\right)$, ambroxol 3 x 7,5 mg po. Planning are electrolytes, calsium, ASTO, CRP, protein, albumin, globulin, liver function, ureum, creatinine, electrocardiography, chest X-Ray, echocardiography, pharyngeal throat swab culture, fluid balance.

Education for management of this case was strict bed rest, provide age-ill-appropriate activities, early diet advice, if overweight, and in failure. Monitoring for temperature, pulse, respiratory rate, blood pressure 4 times daily, if pulse $>100$, hear apical heart rate. The complication that could be happen was a cardiogenic shock, and the prognosis was dubia.

Hemolytic anemia ec suspect autoimmune anemia. We observed the patient and done Coomb's test, malaria parasite, ferritin, saturated iron (SI), total iron-binding capacity (TIBC). Education for frequent blood transfusion and appropriate therapy. Monitoring for complete blood count, peripheral blood smear, reticulocyte count, ferritin, and prognosis for this case is dubia .

Electrolyte revealed sodium $130 \mathrm{mmol} / \mathrm{L}$, potassium $4,1 \mathrm{mmol} / \mathrm{L}$, calcium $7,8 \mathrm{mg} / \mathrm{dL}$.
We treated calcium $3 \times 200 \mathrm{mg}$ po. Total protein 5,7 gr/dL, albumin 3,3 gr/dL, globulin 2,4 gr/dL, ALT $13 \mathrm{U} / \mathrm{L}$, AST 31 $\mathrm{U} / \mathrm{L}$, total bilirubin $4,09 \mathrm{mg} / \mathrm{dl}$, bilirubin indirect $1,56 \mathrm{mg} / \mathrm{dl}$, bilirubin direct 2,53 $\mathrm{mg} / \mathrm{dl}$. Impression: high conjugated bilirubin with high reticulocyte count. Planning was a direct antiglobulin test. Peripheral blood smear revealed no malaria parasite finding. Coomb's test reveals negative. The impression of autoimmune hemolytic anemia was excluded. Planning was repeated peripheral blood count and smear.

The electrocardiogram result was heart position semi-vertical, sinus rhythm, without prolonged interval PR, without arrhythmia, and found $\mathrm{LVH}$ sign.

C-reactive Protein (CRP) reveals positive, and antistreptolysin $\mathrm{O}$ reveals positive. Impression was suitable with acute rheumatic fever and treated with benzathine penicillin 600.000 unit IM and prednisone 3 x $10 \mathrm{mg}$ po.
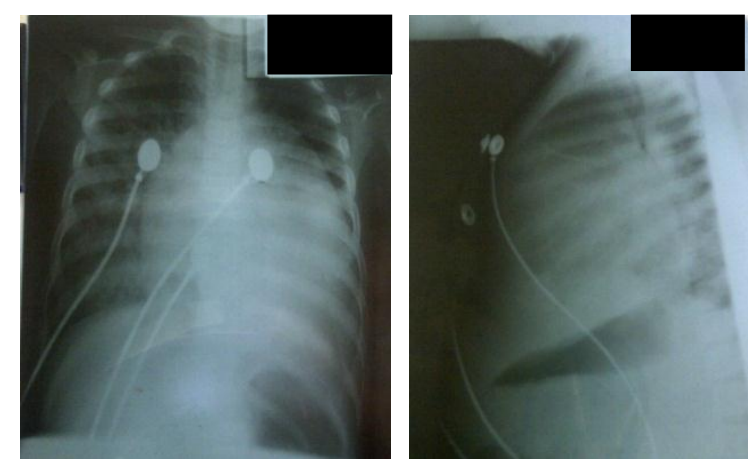

Figure 1. CheST X-RAY

Chest X-ray examination revealed increased pulmonary vascularization with cranialisation, heart enlargement both sides, looks like the jar. Impression: cardiomegaly with pulmonary congestion. Differential diagnosis was pericardial effusion

Echocardiography reveals situs solitus, dilatation of all chambers ec. cardiomyopathy, mitral regurgitation (MR) moderate, left arch, tricuspid regurgitation 
(TR) mild, with TVG $33 \mathrm{mmHg}$, poor LV and RV function (ejection fraction/ EF 15\%). Impression: cardiomyopathy dilatation with MR moderate, TR moderate, poor LV, and $\mathrm{RV}$ function. We added furosemide $2 \times 15 \mathrm{mg}$ iv, captopril $2 \times 4,5 \mathrm{mg}$ po, digoxin $1 \times 0,075$ mg po, monitoring vital sign, liquid balance, sign of digoxin intoxication. Planning: follow up echocardiography after 2 weeks and delayed blood transfusion.

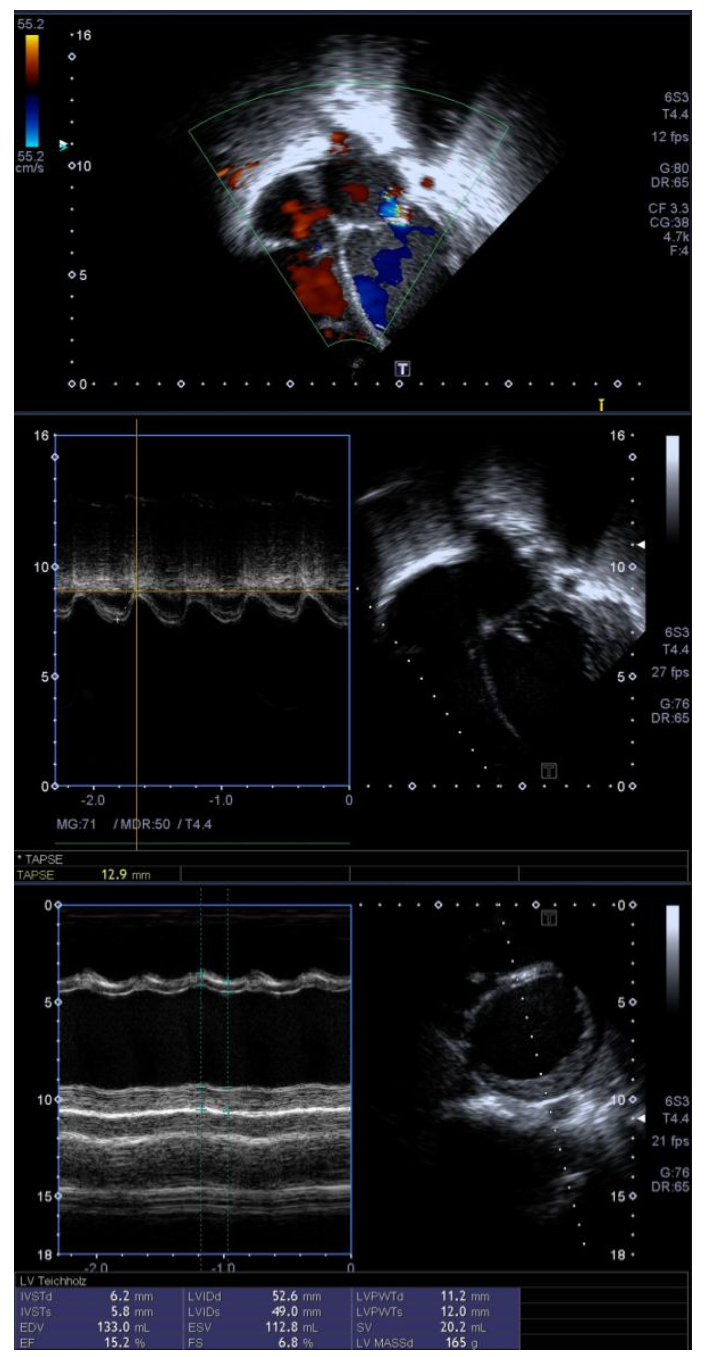

FIGURE 2. FIRST ECHOCARDIOGRAPHY

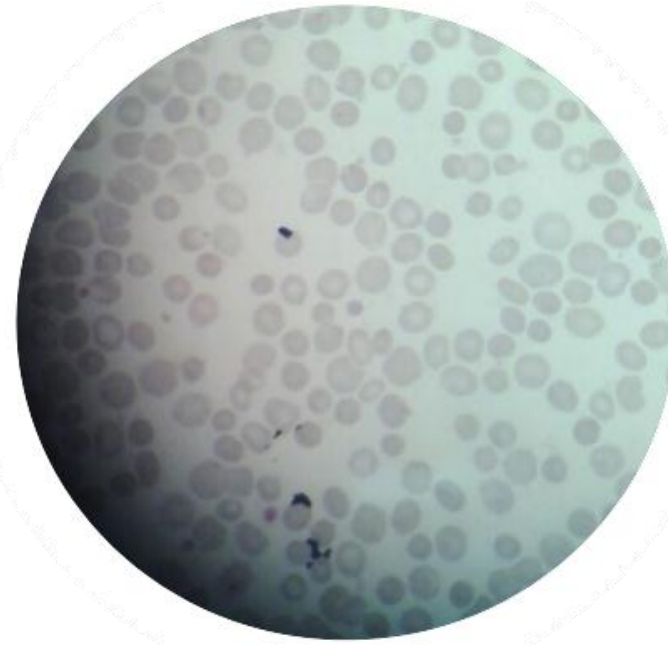

Figure 3. Peripheral Blood SMear

Follow up hematology finding after one week reveals hemoglobin $8,9 \mathrm{~g} / \mathrm{dL}$, leukocyte $10.580 / \mathrm{mm}^{3}$, differential count $0 / 0 / 1 / 78 / 20 / 1$, erythrocyte $3,25 \times 10^{6} / \mathrm{mm}^{3}$, thrombocyte $605.000 / \mathrm{mm}^{3}$, reticulocyte 30,1 $\%$. Peripheral blood smears show normochromic anisocytosis, spherocyte $(++)$, polychromatic, neutrophilia shift to the left, atypical lymphocyte (+), thrombocyte was normal. The interpretation was moderate anemia suspected spherocytosis. The osmotic resistance test reveals the increase of osmotic fragility. Impression of this test suitable hereditary spherocytosis. Both parents reveal normal hematologic findings, and no spherocytes were or hemolytic patterns from the peripheral blood smear. Impression was sporadic or isolated spherocytosis hereditary. Treatment was folic acid 2x $1 \mathrm{mg}$.

On the third week, laboratory finding was total bilirubin $2,22 \mathrm{mg} / \mathrm{dL}$, direct bilirubin $1,99 \mathrm{mg} / \mathrm{dl}$, indirect bilirubin $0,73 \mathrm{mg} / \mathrm{dl}$. Impression: improvement. AST $30 \mathrm{U} / \mathrm{L}$, ALT $42 \mathrm{U} / \mathrm{L}$. Impression was conjugated bilirubin and ALT were increased. Treatments were Curcuma $1 \times 1$ teaspoon. We continued to observed. SI 128, TIBC 468, ferritin $94,4 \mathrm{ng} / \mathrm{ml}(13-400 \mathrm{ng} / \mathrm{ml})$ were not suitable to early iron deficiency anemia. ASTO and CRP were negative showed that the infective process has resolved. Pharyngeal throat swab culture showed no bacterial growth. 
Laboratorium finding reveals hemoglobin $10,1 \mathrm{~g} / \mathrm{dL}$, leukocyte $10.100 / \mathrm{mm}^{3}$, differential count $0 / 1 / 3 / 73 / 21 / 2$, erythrocyte $3,6 \times 10^{6} / \mathrm{mm}^{3}$, thrombocyte $415.000 / \mathrm{mm}^{3}$, reticulocyte $160 \%$. Peripheral blood smears show normochromic anisocytosis, spherocyte (+), polychromatic, leukocytosis, neutrophilia shift to the left, thrombocyte was increased. MCV 88,9 fl, MCH 88,9 PQ, MCHC 33,8 gr/dL. Interpretation: increased hemoglobin and reticulocytosis ec hemolytic process ec. Spherocytosis. Planning: observation and follow up haemolytic process.

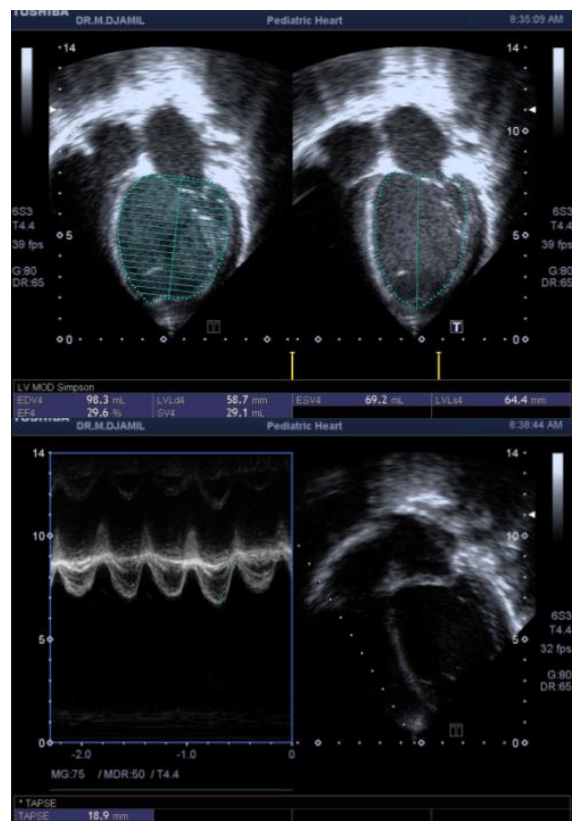

FigURE 4. ECHOCARDIOGRAPHY AFTER 1 MONTH THERAPY

Echocardiography follows up resulted in situs solitus, all chamber dilatation, poor LV, and $\mathrm{RV}$ function (improvement) with $\mathrm{EF}$ $30 \%$, Tapse 1,9 , moderate MR, mild TR, and left arch. Impression: improvement.

The patient was discharged with stressing education on activity limitation for this three months, frequently control once a month, and long-standing prophylaxis benzathine penicillin, dental care, and antibiotic prophylaxis treat sore throat and skin sores early, follow up echocardiography every three months, observe the sign of pale and jaundice and digoxin intoxication, involve the family in care. The most important of education is awareness of both parents about the prognosis of dilated cardiomyopathy, condition of heart contractility, and complication that might be happenned.

This patient was hospitalized 6 month after therapy with suspected Acute Congestive Liver Injury (ACLI). The patient came with massive ascites, congestive heart failure stage IV, heavy cough and jaundice. Total protein $5,1 \mathrm{gr} / \mathrm{dl}$, albumin $2,2 \mathrm{gr} / \mathrm{dl}$, globulin $2,9 \mathrm{gr} / \mathrm{dl}$, impression: hypoalbuminemia, treatment albumin correction with $15,6 \mathrm{cc}$ albumin $20 \%$. Total bilirubin $6,26 \mathrm{mg} / \mathrm{dl}$, indirect bilirubin $1,37 \mathrm{mg} / \mathrm{dl}$, direct bilirubin $4,89 \mathrm{mg} / \mathrm{dl}$, impression: increasing conjungated bilirubin. AST $38 \mathrm{u} / \mathrm{L}$ (increasing 1,3x), ALT $38 \mathrm{u} / \mathrm{L}$ (increasing 1,2x), gamma-GT 28,7 $\mu \mathrm{l}(\mathrm{N}: 5-36 \mu \mathrm{l})$, alkali phosphatase $53 \mu \mathrm{l}(\mathrm{N}<268 \mu \mathrm{l})$, LDH $581 \mu \mathrm{l}$ $(\mathrm{N}<400 \mu \mathrm{l})$, ferritin $288,11 \mathrm{ng} / \mathrm{ml}(\mathrm{N}: 13-400$ $\mathrm{ng} / \mathrm{ml}$ ), ureum $25 \mathrm{mg} / \mathrm{dL}$, creatinin 0,3 $\mathrm{mg} / \mathrm{dL}$.

Chest X-rays reveal pulmonary edema. Electrocardiography results in tachycardia sinus and LVH.Echocardiography results in LV dilatation, MR moderate, TR mild, and poor LV-RV function (EF 26\%). The Nterminal prohormone of brain natriuretic peptide examination (NT-proBNP) was done after six months of therapy because there was research with a result of $31982 \mathrm{pg} / \mathrm{ml}$. Impression: High increase.

\section{DISCUSSION}

We present a case of a 5 years and 6 months old girl with unremarkable cardiac history hospitalized for congestive heart failure due to dilated cardiomyopathy concomitant with acute rheumatic fever and sporadic hereditary spherocytosis. Diagnosis congestive heart failure was made based on a history of stomach became bigger, exercise intolerance, shortness of breath in the last two weeks before admission and 
breathlessness at rest, and sleep lean on two pillows. No history of heart failure before; she was an active and cheerful girl who still can go upstairs in her Kindergarten for one month before exercise intolerance. Dilated cardiomyopathy was diagnosed by echocardiography, which LV dilatation, all chamber enlargement, and poor LV-RV function.

Dilated cardiomyopathy can appear along a spectrum of no symptoms, subtle symptoms, or, in the more severe cases, congestive heart failure (CHF), which occurs when the heart is unable to pump blood well enough to meet the body tissue needs for oxygen and nutrients. When only subtle symptoms exist, infants and young children are sometimes diagnosed with a viral upper respiratory tract infection or recurrent "pneumonia" without realizing that a heart problem is a basis for these symptoms. Older children and adolescents are less likely to be diagnosed with viral syndromes and more likely to present with decreased exercise capacity or easy fatigability ${ }^{8}$.

Acute rheumatic fever diagnosed based on the guidelines for the diagnosis of ARF, which fulfill one mayor, two minor manifestation plus evidence of a preceding group A streptococcus (GAS) infection?. This patient presented carditis, fever, high ESR, or CRP (+), and ASTO (+). The treatment was running well, which the ASTO and CRP was negative after 2 weeks.

A case with concomitant rheumatic fever and dilated cardiomyopathy have been reported in 8 years old boy with presented pain and swelling in the knee, fever, tender hepatomegaly, pansystolic murmur in mitral area, high ESR, high CRP and ASTO, pharyngeal swab throat cultured showed streptococcus pyogenic. DCM was diagnosed after echocardiography. This association infrequently reported previously in the world literature though it has been reported with viral myocarditis. In end-stage dilated cardiomyopathy with clinically suspected acute rheumatic carditis will have a fatal outcome ${ }^{10}$.

Sporadic hereditary spherocytosis was diagnosed based on anamnesis of pale and jaundice, splenomegaly on physical examination, hemolytic anemia, reticulocytosis, spherocytes (+), malaria (-) on hematologic finding and Coomb's test was negative. Sporadic means a child with hereditary spherocytosis with a clinically and hematologically normal parent. The etiology could be an autosomal recessive form (nondominant) of this disease or spontaneous HS due to $\beta$-spectrin de novo mutations ${ }^{11}$. The gold-standard diagnosis of HS was red cell protein-membrane analysis, but it wasn't available in Padang City.

Correlation between dilated cardiomyopathy and hereditary spherocytosis hasn't previously been reported. A case of a 23year-old male was reported with noncompaction cardiomyopathy, which prior episode of intermittent atrial fibrillation, and the patient has been splenectomy six years ago $^{12}$. Another report was 62 years old woman with congestive heart failure and HS, which $\mathrm{CHF}$ related due to chronic severe anemia $^{13}$.

The etiology of dilated cardiomyopathy in this patient might be caused by familial dilated cardiomyopathy or idiopathic. Familial cardiomyopathy suspected because of the history of the mother's sibling who died antepartum because of heart failure due to enlargement of the heart. Peripartum cardiomyopathy (PPCM) is an uncommon type of heart failure of unknown cause occurring late in pregnancy or in the postpartum period. Because of its low incidence and the unspecific symptoms, PPCM is often undetected or misdiagnosed. Unfortunately, PPCM is a disease whose underlying etiology and natural history remain incompletely understood due to its high maternal morbidity and mortality ${ }^{14,15}$. 
Abdominal complaints are a common presenting symptom complex of $\mathrm{CHF}$ in pediatric dilated cardiomyopathy in all age groups. In adolescents, abdominal complaints occur more frequently than respiratory complaints and often in the absence of any other symptoms. Unlike CHF in adults, chest pain, arrhythmia, or cardiac arrest occurs rarely at presentation in pediatric patients. Recognition of the different presenting symptoms of heart failure in children by primary providers is crucial to ensuring prompt diagnosis and timely initiation of therapy ${ }^{16}$.

Dilated cardiomyopathy in this patient was severe, based on poor LV-RV function. Combination treatment among furosemide, captopril, and digoxin show mild-moderate improvement. Any medical treatment in DCM has not improved in several decades. ${ }^{8}$ Heart transplantation was the need for severe DCM, but the procedure hasn't available in Indonesia.

Jaundice, in this patient due to two different mechanisms, there are hereditary spherocytosis and congestive hepatopathy. Hereditary spherocytosis caused jaundice by the form of sludge in the gallbladder until forming gallstone. In this patient, the serial USG showed no sludge or stone in gallblader ${ }^{17}$.

Acute Congestive Liver Injury (ACLI) was suspected because of the increasing of conjugated bilirubin, elevated ALT, and hypoalbuminemia. Liver dysfunction, also known as the cardiohepatic syndrome, reportedly occurs in $20-30 \%$ of patients. It presents in two primary patterns: a cholestasis-like pattern marked by elevations in total bilirubin and alkaline phosphatase, and a pattern of hepatocellular injury characterized by elevations in alanine and aspartate aminotransferases. Both types of dysfunction are associated with increased hospitalizations and mortality ${ }^{16}$.
Kubo et al. in Samsky, examined the incidence of liver disease among 133 patients with chronic systolic HF secondary to dilated cardiomyopathy. Abnormalities in LFTs were common, but generally of small magnitude and primarily limited to patients with a cardiac index $<1.51 / \mathrm{min} / \mathrm{m} 2$. Once primary biliary pathology and systemic conditions that may concomitantly affect the heart and liver have been ruled out, elevated LFTs in conjunction with increased intracardiac filling pressures suggest some component of cardiogenic liver injury. When combined with an average $(<5 \mathrm{~mm} \mathrm{Hg})$ gradient between hepatic wedge pressure and right atrial pressure, one can rule out significant portal hypertension secondary to chronic liver disease ${ }^{18}$.

Prognosis of this patient remain worse because of poor LV-RV function and suspected ACLI, severe ascites, and hypoalbuminemia predict bad outcome. Biomarkers can be of clinical use in the diagnosis, management, and prognosis of patients, especially those with heart failure. The most widely used markers are B-type natriuretic peptide (BNP) and N-terminal pro-brain natriuretic peptide (NT-proBNP). The level of NT-proBNP in serum at 3 months after diagnosis could predict an adverse outcome in pediatric DC and could be used as a guide for long-term treatment plans. NT-proBNP level $\geq 381 \mathrm{pg} / \mathrm{ml}$ at 3 months after diagnosis showed an increased risk of severe LV dysfunction or cardiac death in Busan, Korea ${ }^{19}$. The prognosis of this patient was bad, based on the NTproBNP level.

\section{REFERENCE}

[1] Perry E. Diagnosis and management of dilated cardiomyopathy. Heart 2000;84:106.

[2] Park MK. Primary Myocardial Disease. In: Fletcher J, ed. Pediatric Cardiology for Practitioners. 5 ed. Philadedelphia: Mosby Elsevier; 2008:341-8.

[3] Gagliardi MG. Dilated cardiomyopathy in children. Acta Paediatr 2006;95:14-6.

[4] Kirk R, Edwards L, Aurora P, et al. Registry of the international society for heart and lung 
transplantation: twelfth official pediatric heart transplantation report-2009. J Heart Lung Transplant 2009;28:993-1006.

[5] Towbin J, Lowe A, Colan S, et a. Incidence, causes, and outcomes of dilated cardiomyopathy in children. JAMA 2006;296:1867-76.

[6] Ing RJ, Ames WA, Chambers A. Paediatric cardiomyopathy and anaesthesia. $\mathrm{Br} \mathrm{J}$ Anaesth 2012;108:4-12.

[7] Hollander SA, Bernstein D, Yeh J, Dao D, Sun HY, Rosenthal D. Outcomes of children following a first hospitalization for dilated cardiomyopathy. Circ Heart Fail 2012;5:437.

[8] Harmon WG, Sleeper LA, Lipshultz SE. Treating children with idiopathic dilated cardiomyopathy (From the Pediatric Cardiomyopathy Registry). Am J Cardiol 2009; 104 (2):281-321.

[9] Gerber MA, Baltimore RS, Eaton CB, Gewitz M, Rowley AH, Shulman ST, Taubert KA. Prevention of rheumatic fever and diagnosis and treatment of acute streptococcal pharyngitis: a scientific statement from the American Heart Association Rheumatic Fever, Endocarditis, and Kawasaki Disease Committee of the Council on Cardiovascular Disease in the Young, the Interdisciplinary Council on Functional Genomics and Translational Biology, and the Interdisciplinary Council on Quality of Care and Outcomes Research.Circulation. 2009; 119:1541-155110.

[10] Amritanshu K, Banerjee D P. Concomitant Rheumatic Fever And Dilated Cardiomyopathy: A Case Report. Pediatr Oncall J. 2013;10: 24-25. Doi: 10.7199/Ped.Oncall.2013.12

[11]Giudice EMd, Nobili B, Francese M, et al. Clinical and molecular evaluation of nondominant hereditary spherocytosis. Brit Jour Haem 2001;42-7.

[12] Alter P, Maisch B. Non-compaction cardiomyopathy in an adult with hereditary spherocytosis. Eur Jour of Heart Fail 2007;9:989.

[13] Morita M, Hashizume M, Kanematsu T, Sugimachi K, Makizumi K. Hereditary spherocytosis with congestive heart failure: report of a case. Jpn J Surg 1993;23:458-61.

[14] Serio A, Kodama T, Favalli V, Arbustini E. Familial dilated cardiomyopathy. Herz 2012;37:822-9.

[15] Groesdonk HV, Dinse-Lambracht A, Doblanzki W, Doblanzki U, Galm C, Muth C-M. Unrecognized peripartum cardiomyopathy: case series and comprehensive review of the literature. Cardiopulmonary Pathophysiology 2009; 13:237-42.

[16] Hollander SA, Addonizio LJ, Chin C, et al. Abdominal complaints as a common first presentation of heart failure in adolescents with dilated cardiomyopathy. Am J Emerg Med 2013;31:684-6.

[17] Bolton-Maggs PHB, Stevens RF, Dodd NJ, Lamont G, Titiensor P, King MJ. Guidelines for diagnosis and management of hereditary spherocytosis. Brit Jour of Haem 2004;126:45574.

[18] Samsky MD, Patel CB, DeWald TA, et al. Cardiohepatic Interactions in Heart Failure. J Am Coll Cardiol 2013;61:2397-405.

[19] Kim G, Lee OJ, Kang I-S, Song J, Huh J. Clinical Implications of Serial Serum NTerminal Prohormone Brain Natriuretic Peptide Levels in the Prediction of Outcome in Children With Dilated Cardiomyopathy. AJC 2013;112:1455-60. 